\title{
Land Ownership Reform in Islam
}

\author{
Ridwan $^{1}$ \\ ${ }^{1}$ Shari'a Faculty of State Institute for Islamic Studies, Purwokerto, Indonesia \\ Correspondence: Ridwan, Shari'a Faculty of State Institute for Islamic Studies, Purwokerto, Indonesia. Tel: \\ 62-815-656-9509. E-mail: ridwan@iainpurwokerto.ac.id
}

Received: November 22, 2018 Accepted: December 5, $2018 \quad$ Online Published: January 30, 2019

doi:10.5539/ass.v15n2p164

URL: https://doi.org/10.5539/ass.v15n2p164

\begin{abstract}
This article shows that Islam has laid the foundations of agrarian law reform or land reform, from the oppressive and exploitative pre-Islamic system of land ownership towards the fair, equitable and humanist-religious-based distribution of land ownership. The purpose of agrarian reform cannot be separated from the objectives of the law in general, that is to create justice, expediency and law certainty which describe the legal values either juridical, sociological or philosophical. To explain the idea of agrarian reform in Islamic law, there are some discussions proving the existence of the notion of land ownership reform in terms of the process of land right ownership and patterns of land distribution by the State based on the historical data, especially early history of Islam. Shifting paradigm from the feudalist pre-Islamic ownership system to the communalist-religious Islamic ownership system under the single authority of the head of state on the basis of the principle of fairness rests on the spirit to realize the ideals of public benefit.
\end{abstract}

Keywords: land reform, Islamic law, land distribution, humanistic, religious justice

\section{Introduction}

The existence of land has religio-cosmic significance besides its economic value. Land is an important asset for economic development utilized by varying actors ranging from an individual to the large organization and government agencies (Hamzah et al., 2013). Land with its various contents and functions to the humankind, is the most important production factor. Humans as a creature of God are mandated to manage the earth and its contents in their capacity as Khalifah in the earth. Such human's chaliphate roles on earth make it necessary for them to have the ability to manage the earth properly and correctly (Zuhayli, 1992). In Islam, land has theological, in addition to economic, significance. It is believed that land is the core element for the creation by God for humans. The belief makes muslim always be reminded that every human comes from the ground and going back to the ground. Men should be able to manage the land as an instrument of obedience to God by using their lands in line with the rules outlined by God (Bashir, 2002). In other words, land is an important instrument of worshipping, economic, social and political activities in creating a prosperous society order.

The history of land law development has been presenting the diversity of people's perception about the position and meaning of land as property. The diversity of perception is mostly influenced by the diversity of people's beliefs, cultural backgrounds and social perceptions about the nature of land. The multidimensional perspectives in looking at and giving meaning to land lead to the diversity of human ways in treating land amidst many interests, either economical, social, political or religious, surrounding the existence of land.

The diversity of people's perception in understanding and positioning land leads to tense relations either among individuals, individuals with their social environment, or individuals with the state. This is possible because the nature of land is constant (Siddiqui, 1996) and, in the same time, the number of people requiring lands increases from time to time. In the course of history, the growth of land ownership rights has shown a dynamic development in accordance with the time dynamics (Iqbal, 2000).

The notion of agrarian reform in Islam, especially in terms of land ownership law, can be seen in some elements of the agrarian reform program launched by the Prophet and his companions in the course of history. The objectives of agrarian reform in Islam cannot be separated from the objectives of the law in general: to create justice, usefulness and legal certainty.

In Islam, land ownership by an individual in the context of social relation is legally recognized. Land owners have authority to utilize their lands on their own will. Men's authority over property ownership under Islamic 
Jurisprudence is protected within the frame of property protection as one of the five principles in Islam (al-Kulliyah al-Khams). As stated above, land has socio-humanistical contents, in addition to its economical function. Therefore, it is not allowed in Islam to monopolize assets or property. Thus, property ownership by an individual should be accompanied by moral responsibility.

The term land reform is the same in meaning as agrarian reform, although the latter has a broader meaning. Land reform is the effort to reorganize the land ownership and possession structure in view of creating justice, especially for those whose livelihoods depend on agricultural production. Land reform programs include, among others, land redistribution program, employment provision in agricultural sector, credit assistance program to support investment in agriculture, and the availability of market opportunities for agricultural products. Therefore, the land reform program is not only intended to reduce rural poverty rate and promote the growth of agricultural sector, but also in order to build a social foundation to accelerate the pace of industrialization.

This study uses a historical approach by reconstructing historical facts on the practice of land ownership pre-Islam and the period of Islam. The dialogue of land ownership in Arabians at pre-Islam with Islamic legal engender assimilation process and adaptation among tradition thus giving new tradition of land ownership by synthesis.

This article refers to classical Islamic reference source in the field of law and Islamic economic history in the period of early Islam by using qualitative analysis with the content analysis approach and dialectical hermeneutic. The basic concept of land regulation in history is analyzed to give engender with relations that influence each other. This method use data reduction, then present and describe data systematically and finally the author gives an interpretation of that data.

\section{Pre-Islamic Land Ownership Practices}

The tradition of feudalist economic arrangements was an established practice in pre-Islamic era outside the Arabian Peninsula by the Roman and Persian Empires. Economically, the community was divided into two, the rich and the poor. The rich class consisted of the king and his family, royal officials and landowners who control production resources, while the poor class consisted of farmers and craftsmen (Ra'ana, 1997). This system presupposes the existence of social classes describing exploitative relationship between the rich and the poor.

The pre-Islamic social structure of the Arabs was that some of them lived sedentarily in particular places and others lived nomadic life moving from one place to another. People who lived sedentarily in particular places, both in urban and rural areas, were familiar with the individual ownership and their existences were acknowledged. Each individual was free to use and enjoy his property with security protection provided by their tribes/clans. Private property rights, especially the rights to own lands and live in houses, as known by the Arabs, especially among people who lived sedentarily in Yathrib, e.g.: Aus and Khazraj tribes and the Jewish community owned their respective plantations and agricultural fields. Jewish groups, in general, possessed fertile plantations (Watt, 1956).

The Arabs who lived nomadic life, in contrast, did not recognized land ownership or private houses. They lived moving from one place to another to look for grass and oases as their sources of livelihoods. Even if there was a war between tribes, their motive was not to possess the defeated tribe's lands, but to seize and possess their livestock and property. Land possesion practice among them was the collective claim of ownership over lands owned by their tribe as a protected ground called hima- (Zuhayli, 1992) as grazing areas for their livestock. Hima right owned by a particular tribe was an exclusive property of the concerned tribe and other tribe members should not take advantage of the hima land. In other words, in the nomadic Arab society, the prevailing system of ownership is a collective system which belongs to tribes.

In addition to collective ownership mentioned above, there was also individual land ownership that is the ownership right held by the tribe leader or respectable people among the tribe members for their own sake. When the tribe leader required a certain land for himself and his family, he took the high ground and made his dog barking. The boundaries of his private land was the longest distance of the dog's bark could be heard. The pre-Islamic practice of land ownership described patterns of unequal power relations between the poor and the rich, between the rulers and their people.

\section{Land Ownership in Islam}

When Islam came to the Arabian Peninsula, the unfair and oppressive land ownership system was then responded by Islam. Ownership is known in Arabic as al-milkiyyah or al-milk, which signifies holding a thing and the ability of exploiting it. Ibn Manzur mentions that the terms malk, mulk and milk refer to the state of containing a thing, and the ability to dominate and dispose of (bin Nik Abdul Ghani, Saleem, \& Lahsasna, 2015). 
The land and plantation ownership structure practiced by the sedentary Arabs both in cities and in villages was then justified by the Qur'an as a recognized form of ownership as is mentioned in chapter Alì Imrān verse195 and chapter al-Hashr verse 2 .

Land ownership is also justified by the Tradition of the Prophet by applying the concept of war loots in which soldiers who participated in a war were given parts of the conquered lands, as happened to the land of Khaybar. Similarly, the Anshar companions who incidentally farmers and gardeners also got legitimacy over the existence of individual land ownership.

The tradition of land possession during the pre-Islamic era is often done by means of hima which is making a protected land by a certain tribal figure either for the sake of himself or his family sake or members of his tribe, in order to control water and grass resources to sustain their lives and their livestock. The possession was achieved by force or conquest by the stronger tribes over the weaker tribes (al-Khatib, 1989). Land possession through the hima-method was not accompanied by clear boundaries on land they possessed.

Such practice of land possession through hima was rejected by Islam as inhumane and relying more on the power or even violence. The Prophet, with his Islamic teachings, developed a regulation of land ownership both on the side of its philosophy and way of acquisition. Hima as an institution of land arrangement has been adopted by Islam with several revisions. First, the concept of hima should only be performed by caliph and should not be performed by individuals. Second, the orientation of hima is not for self-enriching, but for the public benefit.

Reform of land ownership through hima ${ }^{-}$from its pre-Islamic practice to Islamic one is very clearly based on the Prophet "hima" belongs solely to God and the Prophet," (Shafi'i, n. d.) its means that hima is aimed for the benefit of the community, so that the land of hima is often referred to as common land. Mean while hima refer to Prophet, can only be performed by caliph who has the political authority to regulate society (Qudamah, n.d.). The hima ${ }^{-}$right has exclusive right of head in Islam as a form of government intervention in the context of legal regulation of land ownership on the basis of the public benefit value of equitable and fair land ownership system (Iqbal, 2000).

The Prophet, in his capacity as an imam, had the authority to set rules of law in the context of national life. In other parts, the Prophet also described his right to make limitations on the use of property rights to land. An imam right to regulate of the use of land, of course, based on the rational, logical and objective grounds built on the spirit of realizing the public benefit as a fundamental duty of head of state (Abdurrahman, 1996). It is stated in an Islamic legal maxim that a head of state policy should be oriented towards creating the public benefit.

According to Muhammad Baqir Sadr, the Islamic doctrine in looking land ownership rights is more communal in its dimension. Based on its authority, the government can transform personal properties into public ones. This shows that collective ownership is much more powerful than personal ownership (Sadr, 1981). The idea of nationalizing personal assets to be public assets based on the consideration of public benefit is referred to ta 'mim, namely a process of transformation of personal land ownership rights into collective ones by the State.

Paradigm of hima as pre-Islamic concept of land ownership which was more personal nature and aimed for selfor group-enriching was shifted by Prophet into public interests and for the purpose of the public benefit. Prophet himself took a policy of hima land acquisition in the area of al-Naqi for the benefit of Muslims' horses grazing. Similarly, it was conducted by the Caliph Umar ibn Khattab who made hima to the lands in Rubdhah and Sharaf areas. Based on the practice of hima- done by Prophet, it is clear that hima ${ }^{-}$lands were common property and were used for the public benefit, i.e. to graze horses which were used for war. The concept of hima ${ }^{-}$in Islam is the concept of land ownership by the State for public interests.

Pre-Islamic practice of hima- was a recorded by feudal Arab social system of that time which was characterized by monopoly in land ownership. Lands were owned by authority and the practice was then reformed by Islam. Prophet himself directly gave an example of how the process of land redistribution in the interests of the general public. The Prophet had ever distributed the land of Khaybar into 26 sections, and each section was then redistributed into 100 sub-sections. The Prophet then took for himself half of the land, 1300 sub-sections, which he then distributed to the governors, troop commanders, heads of government and other purposes in the government, while the other 1300 subsections were given to the rest of moslems.

What Prophet did, actually, in order to deconstruct the land distribution system during pre-Islamic era which was feudalistic in nature in which lands were distributed only to troop commanders and high-level officials of the state and were only given to the church. Land ownership rights were deprived from the original owners, and then they became peasants or land managing slaves. Thus, it was born a new relationship of land ownership, an 
oppressive relationship between employers/landlords with slaves (Ra'ana, 1997). Even if the original owners were provided with the right to work the land, they were still burdened with high taxes. The practice prevailed in Iran and the Roman before conquest of the area.

\section{Land Ownership Reform in Islam}

The practice of land possession by the state over the territories conquered by Moslems have been going on since the time of Prophet Muhammad. The first land of the conquered territories possessed by Moslems at the time of Prophet is the Clan of Nadhir's land after Prophet's migration to Medina when the Clan of Nadhir betrayed their agreement with moslems that led to the expulsion of the Jews from Medina (Qudamah, 1988). All the spoils of war, especially the movable ones, were distributed by the Prophet to people who are in need such as the Muhajirin companions, the poor and the destitute, as for unmovable spoils of war, i.e. lands, were not distributed but possessed by the state. The state had the right to give the lands to some people called iqta'(Iqbal, 2000) either as right of ownership or just rights to use. The ownership right over lands possessed as spoils of war from the Clan of Nadhir belonged to the state from which it benefitted from the results of the land to finance the operations of the state for social welfare. This Iqta is the institutionalization of the land redistribution program as a part of the land reform program undertaken by Prophet. Clan of Nadhir's land possession by the state proved that the basic principle of land ownership in Islam is that it belongs to the state (Iqbal, 2000).

Then, in the fourth year of his hijra, the next land possession was the land of the Jewish community of Khaybar who had violated the treaty of Hudaybiyah they have agreed with Moslems. Regarding the movable spoils of war, Prophet distributed them to the soldiers who participated in the war, while the agricultural lands were owned by the state and their cultivation was returned to the native people with profit sharing system (Qudamah, 1988). Similarly, the case was the same as the land of Fadak. When the Prophet took possession over the land, the cultivation of the agricultural lands was done by local natives with profit sharing system, which later is known by the Jurists as land rental in the frame of ijara. Prophet's policies regarding the management of the conquered lands were then recognized during the next period of Khuläfa' al-Rasyidun.

The system of land ownership at the times of Prophet and the Caliph Abu Bakr had not been arranged neatly and permanently, since there was no need for such arrangement. When 'Umar ibn Khattab took the Caliphate with his program of Islamic territorial expansion beyond Arabian Peninsula, he changed feudalistic system of land ownership. According to him, the whole conquered lands are public lands controlled by the State. The natives were given right to cultivate their lands with the obligation of paying land tax or kharraj each year.

It is told in a tradition that after conquering Sawad territory in Iraq, the Islamic troops asked their commander, Saad ibn Abi Waqqas, to distribute the conquered land to them. Saad then conveyed it to 'Umar ibn al-Khattab through a letter. Receiving the letter, 'Umar ibn Khattab replied that the land are to be distributed to the Moslems or to the local population with the obligation to pay taxes. The reason is that when the land is entirely distributed, then what will happen to the next generation (Salam, 1986).

The same case also occured in the conquest of Egypt. There were the pressure from the senior companions such as Abdurrahman ibn Awf and Bilal as well as other companions to Amr ibn Ash as the commander in the region. Finally, 'Umar ibn Khattab gathered the companions to discuss this issue and told them that the conquered land was not to be distributed to the soldiers but was returned to the local population to be worked on and they are required to give taxes to the State. The reason of Caliph Umar was that the State requires operational funds to pay salary of the soldiers guarding the borders of Islamic territories for territorial integrity of Islam, in addition to preparing the ground for future generations (Ibrahim, 1987).

Umar ibn Khattab's refusal to distribute the conquered land to the soldiers was a far-reaching policy within the framework of the eradication of the feudalism practice in the region (Ra'ana, 1997). Although Prophet ever distributed the land of Khaybar to the soldiers and other Muslims, the land was a bit in number, so it would not lead to a landlord practice. The lands conquered in Egypt and Iraq were large in scale. So, when the lands was divided, it likely led to the creation of landlords and, in turn, would lead to new destruction. Umar's framework of thinking is very clearly philosophical-oriented which was built on the value of the public benefit of society as the main axis of his ijtihäd. Such text interpretation approach taken by Umar ibn al-Khattab is often called as a contextual approach.

Policies in land law taken by Umar ibn Khattab, in addition to avoid the concentration of wealth in the hands of certain people, show the basic principle of assets ownership, including land ownership, as the rights of all people, in which the control is on the State. Therefore land law-related policies should consider the welfare of the next generations (al-Khatib, 1989). Umar ibn Khattab's policies also imply the existence of program of nationalization of agricultural land assets as belonging to the State. In views of the majority of figh scholars, 
Umar ibn Khattab's policies are based on value of public benefit as the core of Shari'a, eventhough it is in contrast with the literal Qur'anic text of ghanimah verses. However, it is relevant when is associated with surat al-Hashr verse seven about the distribution of war loots $\left(f a^{\prime} i\right)$ whose basic principle is the prohibition of the concentration of wealth in particular people. Caliph Umar's policies in structuring land ownership law are called by S.A. Siddiqi as the restoration policy, meaning improving system of land ownership law to creating a fair system of land ownership (Siddiqi, 1996).

In view of Umar ibn al-Khattab, Muslims at the time had been sufficient in terms of land ownership and possession. Even Umar ibn Khattab ever issued a regulation barring the ownership of land by issuing a ban on buying land, because it was feared there would be an accumulated land possession by a person which, ultimately, would lead to monopolistic practices of land ownership. Abu Ubayd told a story that ibn Utba ibn Farqad bought some portions of land on the banks of the Euphrates, Umar then asked him, "From whom did you buy this land?" Utbah replied "from the owner" Then Umar said "return it back to the owner of the land, and ask your money back" (Ra'ana, 1997).

Other Umar policy is to prohibit Moslems scattered in various conquered regions not to work in agricultural sector. This policy then applied by Umar to all conquered regions through letters to the provincial governors stating that Arabs receive a fixed salary from the State, therefore they should not take part in agricultural sector. Caliph Umar ordered that the lands remain in the hands of the previous owner who had had capability in farming. This policy stemed from the report of Musa Ash'ari that there had been slavery practices by the land owners in the conquered regions. In a letter sent by Umar to Musa Ash'ari it was said that "Agriculture is not a suitable field for the Arabs. Therefore, free the slaves and collect taxes from them". Umar's prohibition to the Arabs to take a management role in agriculture was a land reform program both in its distribution and management aspects on the basis of the public benefit. Umar refused the land distribution that lead to monopoly practices which potentially develop feudalistic culture since such practice will lead to deprivation of public rights. In addition, in terms of land management, it should be based on the principle of professionalism. According to him, it is not fair to give large portion of land to some people, while others cannot afford their everyday needs. That is why Umar did not take agricultural lands of Moslems in Yemen, Najed, Taif and Medina.

Another land reform program introduced by Umar was the program of land rights redistribution, namely the takeover of personal rights over land by the state to be distributed to other Moslems. Land redistribution program is related to the increase of population within the limited availability of land. In regard to this policy, there is a case of Jabir ibn Abdullah al-Bajali. When Jabir and his tribe were sent to Iraq, Umar gave promise to Jabir that if they had conquered Iraq, they would have been given a quarter of the conquered land. When the battle was over, the promise was fulfilled. But three years later, Omar asked Jabir to return the land back given the increasing number of Muslims. When Jabir returned the land, Umar gave him compensation of 80 dinars taken from Umar's personal assets (Ira M., n. d.).

Land distribution program for particular types of lands conquered at the time of Umar was given to the soldiers and government employees as their salary. Types of lands given to them were, among others, Sawafi land, namely the agricultural lands left by the rulers conquered such as Sasanian ruler. The land ownership tradition in Islam experienced interesting development when the caliph Uthman ibn Affan reigned (644-656 AD) after the acquisition of the east territory of Persian and the west territory of Roman under the rule of Islamic government. In such a position, occured a dialogue between the Islamic system of land ownership and the Roman one, especially in the region of Sham under the Governor Mu'awiya ibn Abi Sufyan. In the Roman tradition, the lands were possessed by the landlords who lived in luxury, while the slaves who worked on their lands lived in miserable.

The development of land management as the state's assets was also a serious concern during the reign of Caliph Ummayads and Abbasids. During the reign of Caliph al-Ma'mun (813-833 AD), for example, the establishment of goverment structures in conquered territories from the provincial level down to the bottom level was intended to, among others, administering land ownership and use, especially for the sake of state's income tax administration. Legal institution of iqta', namely the government right in land administration was classified into two, i.e. iqta' tamlik and iqta' istighlal. Iqta' as a land administration system by the State can be granted to individuals personally or to the parties which were considered meritorious to the government such as the court officials and military personnels as political retribution (A.K.S., 1998). Iqta' policy was also applied during the Mamluk and Fatimid dynasties given to the Amir, Wazir, Heads of diwan as reward or salary from the government (Iqbal, 2000). The uncontrolled iqta' policies led to the emergence of new landlords particularly among the military elite that tends to change the social system into the feudal in which the landlords exploited the landless workers (Sayyid, 1989). In the analysis of Ira M. Lapidus, the uncontrolled iqta' policies made 
rooms for the emergence of the opposition of local leaders against the central government. The governor seemed to be minor kings with continuously decreased level of loyalty marked by the refusal to pay taxes to the central government that ultimately led to the movement of rebellion. Policies of land law in Islamic history clearly illustrate the relationship between the land reform program in the form of iqta' and the political agenda. In addition, it appears that the land issue in Islam are positioned as a public issue in which the land possession right is hold by the government and, therefore, its regulation is on the government authority.

Policies of Islamic land law reform are evident when compared to pre-Islamic system of land ownership, as shown in the following matrix (Ridwan, 2010):

\begin{tabular}{|c|c|c|}
\hline Aspect & Pre-Islam & Islam \\
\hline Ideology & Feudalistical & Religious-communalism \\
\hline Policy Orientation & $\begin{array}{l}\text { Land possession for the sake of local } \\
\text { rulers/ elites (clan/ tribal leaders and } \\
\text { their deputies) }\end{array}$ & $\begin{array}{l}\text { Public welfare based on the principle of justice } \\
\text { (al-adalah) and equality (al-musawah). }\end{array}$ \\
\hline Strategy & $\begin{array}{l}\text { Acquisition of people's land or no } \\
\text { man's lands for the sake of elites. } \\
\text { Feodalism institutionalizing }\end{array}$ & $\begin{array}{l}\text { Land ownership structuring through land reform } \\
\text { program (al-islah al-zira } i)\end{array}$ \\
\hline $\begin{array}{l}\text { State/Power } \\
\text { Intervention }\end{array}$ & $\begin{array}{l}\text { Intervention by local rulers /tribal } \\
\text { leaders personally for self-enriching } \\
\text { through the instruments of hima dan } \\
\text { iqta. }\end{array}$ & $\begin{array}{l}\text { Conducted by the head of the state in the name of the } \\
\text { state (institution) through the instruments of hima and } \\
\text { iqta' with an orientation different from what was } \\
\text { practiced in the Pre-Islamic period. }\end{array}$ \\
\hline Principle & Wealth accumulation for rulers & $\begin{array}{l}\text { Land for the welfare of cultivating farmers or those in } \\
\text { service of Islamic development }\end{array}$ \\
\hline Perspective/Concept & Land as an exploitation object & $\begin{array}{l}\text { Land as a trusted entity from Allah should be managed } \\
\text { by the state for public welfare (maslahah ammah) } \\
\text { through the land reform programs. } \\
\text { Land has theological, economic, social and political } \\
\text { dimensions. }\end{array}$ \\
\hline Social Function & $\begin{array}{l}\text { Feudalist economical function, } \\
\text { especially for the benefit of local rulers. }\end{array}$ & Social, humanistic and religious function of land use \\
\hline Release of Rights & $\begin{array}{l}\text { Right release on the basis of rulers' } \\
\text { needs and interests through the right of } \\
\text { hima or spoils of war. }\end{array}$ & $\begin{array}{l}\text { Right release for public interests by the state is allowed } \\
\text { only on the basis of public benefit along with the } \\
\text { provision of appropriate compensation. }\end{array}$ \\
\hline
\end{tabular}

In the Quranic, the land, the sky and the earth and everything in them belong to God. In other words, the land is a gift of God that is not bound and is universal in nature, just as water, air, sunlight and others which are all destined to be used for the benefit of all the human beings (Alfred, 2014). Land is a free gift from God. Since the land is an important factor of production, the way of its ownership should be distinguished from other production factors. The presence of land precedes human presence in the world. Based on its important position, in case of land owners abusing their ownership rights, the state has the authority to force them to use their lands appropriately or even withdraw the rights to be given to others in order to make the lands more beneficial (Rahman, 2016).

In Islamic law, land has a public dimension that requires the owner to manage it so that it becomes productive. Prophet himself specifically gave strict instructions to all land owners to cultivate any land owned or, when they are not capable of doing it, leave the land to their relatives/someone else to work on it (Nasai, 1991). The above Prophet's instruction clearlys illustrates the position of land which is not as purely private property, but should take a social function.

Islamic perspective in terms of positioning land in the context of its function is different from the concept of land prevailing in medieval Europe at the beginning of capitalism as an ideology. At the time of the French revolution, social perceptions of property rights to land was based on the belief that the property right was something sacred and noble and therefore the rights should not be reduced by other parties. Right over land was seen as an absolute right. Consequently, such perspective led to a social belief that the land owner is the complete possessor, and the land right holders, therefore, have complete freedom to treat their property of their own will. Land owners can use their property for residences, business venues, plantations or even totally let abandoned. With the principle of individual freedom, the concept of land ownership was referred to as the right of eigendom, namely full ownership in which someone has infinite right over land in the name of individualism. Individualism has led 
to the attitude of deification or even consecration of individual ownership as an absolute right. It is such practice then changed by Islam by reforming land ownership on the basis of the values of justice and humanity.

\section{Conclusion}

Land ownership in Islam should be based on the principle of justice by eliminating monopolistic ownership that leads to feudalistic culture. This is in contrast to the pre-Islamic system of land ownership that put tribal leaders as the holders of indefinite land possession right for the benefit of themselves and their families. There has been paradigm shift from exploitative feudal ownership system to the communal-religious ownership system under the single authority of the head of state on the basis of the principle of justice built on the spirit of realizing the ideals of the public benefit.

The nature of land ownership in Islam is more public in dimension since the land issue is related to the life needs of many people and is an important instrument in the economic as well as religious activities. Therefore, the state as a public institution has the authority to make a wide range of regulatory tools to manage land issues.

Government's authority in making the regulation of land law is based on its right called iqta' and hima. When the government (imaim) will conduct land acquisition based on its authority of iqta', people or the parties whose lands are acquired have the right to redress or compensation which is taken from State treasury based on the value of social propriety ('urf) decided by concerned parties in the principle of mutual willingness. Islamic land law reform includes aspects of distribution, redistribution, professional land management, limitation of land possession and compensation over land rights withdrawal by the government for public use.

\section{References}

Abdurrahman, al-S. (1996). Assbah wa al-Nadaīr. Beirut: Dar al-Fikr.

Alfred, M. (2014). Principles of Economics (Palgrave Classics in Economics) (8th ed.). London: AIAA.

Hameed, M., \& Bashir, A. (2002). Property rights, institutions and economic development: An Islamic perspective. Humanomics, 18(3), 75-91. https://doi.org/10.1108/eb018877

bin Nik Abdul Ghani, N. A. R., Saleem, M. Y., \& Lahsasna, A. (2015). Beneficial ownership: To what extent it complies with shari'ah? Asian Social Science, 11(27), 155-167. https://doi.org/10.5539/ass.v11n27p155

Hamzah, J., Er, A. C., Aliasak, M. H., Habibah, A., Buang, A., Hussain, M. Y., \& Sivapalan, S. (2013). Development process and its implication on the native land ownership. Asian Social Science, 9(14), 18. https://doi.org/10.5539/ass.v9n14p18

Ibrahim, A. Y. Y. ibn. (1987). Kitab al-Kharraj. Pakistan: Idarat al-Qur'an wa al-'Ulum al-Islamiyyah.

Iqbal, N., \& Gill, Z. A. (2000). The Concept of Land Ownership in Islam and Poverty Alleviation in Pakistan [with Comments. The Pakistan Development Review, 649-662. Retrieved from http://www.pide.org.pk/pdf/PDR/2000/Volume4/649-662.pdf

Ira M., L. (n. d.). A History of Islamic Societies (2nd ed.). Cambridge: Cambridge University.

al-Khatib, M. I. (1989). Al-Nidham al-Iqtisad fi al-Islam. Riyadh: Maktabah Haramayn.

Lambton, A. K. (1988). Continuity and change in medieval Persia. SUNY Press.

al-Nasai, A. ibn S. A. A. (1991). Al-Sunan al-Kubra: Book 3. Beirut: Dar al-Kutub al-Ilmiah.

Qudamah, M. ibn. (n. d.). Al-Mughni. Beirut: Dar al-Ma'arif.

Qudamah, M. ibn. (1988). Al-Kafi fí al-Fiqh ibn Hanbal. Beirut: Al-Maktabah al-Araby.

al-Qutb, Sayyid. (1989). Al- 'Adatah Al-Ijtima'iyyah fi al-Isläm. Cairo: Dar al-Shuruq.

Ra'ana, I. M. (1997). Economic System Under Umar The Great. (Mansuruddin Djoely, Ed.). Jakarta: Pustaka Firdaus.

Rahman, A. (2016). Economic Doctrines of Islam. (Soeroyo dan Nastangin, Ed.). Yogyakarta: Dana Bakti Wakaf.

Ridwan. (2010). Pemilikan Rakyat dan Negara atas Tanah Menurut Hukum Pertanahan Nasional dalam Perpektif Hukum Islam. Jakarta: Balibang Kemenag RI.

Sadr, M. B. (1981). Iqtishaduna. Beirut: Dar al-Ta'rif lil al-Mathbuat.

Salam, A. U. al-Q. ibn. (1986). Al-Amwat. Beirut: Dar al-Kutub al-Ilmiah.

Shafi'i, M. ibn I. al-. (n.d.). Al-Umm: Book 4. Beirut: Dar al-Kutub al-Ilmiah. 
Siddiqi, S. A. (1996). Public Finance in Islam. New Delhi: Adam Publisher \& Distributors.

Siddiqui, S. (1996). Factors of production and factor returns under political economy of Islam. Retrieved from https://iei.kau.edu.sa/Files/121/Files/153895_IEI-VOL-08-04E-Shamim.pdf

Watt, W. M. (1956). Muhammad at Madinah. Oxford: Clarendon Press.

al-Zuhayli, W. (1992). Al-Fiqh al-Islami wa Adillatuhu. Beirut: Dar al-Fikr.

\section{Copyrights}

Copyright for this article is retained by the author(s), with first publication rights granted to the journal.

This is an open-access article distributed under the terms and conditions of the Creative Commons Attribution license (http://creativecommons.org/licenses/by/4.0/). 